\title{
Hostile reception to US misconduct report
}

Washington. An internal panel this week advised Donna Shalala, the Secretary of the US Department of Health and Human Services (DHSS), to adopt most of the recommendations of a controversial report on scientific misconduct, over the protestations of dozens of scientific groups, including, most recently, members of the advisory board to the National Institutes of Health (NIH) director, Harold Varmus.

The DHHS panel was charged with recommending to Shalala how to implement the report of the Commission on Research Integrity (CRI). The report was mandated by a 1993 law and released last November by the CRI, a 12-member panel of nongovernment scientists, ethicists and lawyers. If adopted, the recommendations would apply to thousands of scientists receiving funds from NIH and other government agencies.

In presenting his panel's 35-page assessment of the CRI report to Varmus's advisory board last Monday, 17 June, William Raub, the head of the panel, said the report "has much to commend it". Many of its recommendations, he said, "would have a positive effect" on research integrity.

The panel's recommendations have been sent to Shalala, who has final authority over whether and how to adopt them. It is not known when she will announce a decision.

The chairman of CRI, Kenneth Ryan, an emeritus professor of obstetrics, gynaecology and reproductive biology at Harvard Medical School, called the panel's product "a fair hearing" and "an appropriate way to go".

The Raub panel deferred judgement on three of the CRI's 33 recommendations two of them the most controversial. Of the latter, the first concerns definitions. The current law governing NIH and many other government grant recipients defines scientific misconduct as "fabrication, falsification, plagiarism" or other practices that "seriously deviate" from scientific community norms. The National Academy of Sciences (NAS) uses a similar definition. The CRI replaces these words with "misappropriation, interference and misrepresentation", a definition that critics have called vague and too broad.

The Raub panel said that, because of the "decidedly negative tenor" of reaction to the proposed definition, Shalala should make an official request for comment on the definition before making a decision. This request, however, should be delayed to coordinate with the timetable of a working group of the National Science and Technology Council, which is developing a government-wide definition of scientific misconduct.

The other controversial recommendation is a 'whistle-blower's bill of rights'. The Raub panel says that the CRI report, while it evidently "envisioned a judicious balance", creates "a strong initial impression that the Commission was more attentive to rights of whistle-blowers and the responsibilities of other parties" than vice versa.

Nonetheless, it says, regulations protecting whistle-blowers must, under the 1993 law, be established by Shalala, and the CRI's report should be taken into consideration by the NIH office now charged with developing them, the Office of Research Integrity.

At last Monday's meeting, several members of Varmus's advisory board protested. "This [CRI] report is a disaster" and would create an "extremely destructive" atmosphere, said Marc Kirschner, chair of the department of cell biology at Harvard Medical School, who also complained that the CRI contained no "distinguished" scientists.

Paul Marks, president of Memorial Sloan-Kettering Cancer Center, insisted that watchfulness over integrity "has to be at the institutional level" and cannot be imposed by government. The president of NAS, Bruce Alberts, who also spoke to the NIH group, said the CRI report would be "very disruptive" if adopted, in part because of the intrusive federal bureaucracy involved.

Ryan, CRI chairman, retorted later that he has heard these arguments before, and that the fact that little has changed since a 1992 NAS report on scientific misconduct justifies his committee's suggestions.

The Raub panel rejected four of the CRI recommendations: a requirement that the investigation of misconduct complaints and their adjudication be carried out by separate bodies; a mechanism to review the department's enforcement of misconduct laws; a requirement that the results of misconduct cases be widely disclosed, including the names of accused scientists who have been exonerated; and a requirement that intramural NIH programmes deliver the same assurances and annual reports on misconduct as extramural institutions now have to.

It accepted, however, another controversial proposal requiring institutions to run an educational programme on responsible research conduct and to ensure that all grant recipients attend it. Meredith Wadman

\section{Sparks fly over climate report}

London. Controversy about the rewriting of a key chapter in a United Nations climate change report erupted into open hostility last week when a former president of the US National Academy of Sciences suggested that the rewrite amounted to a "disturbing corruption of the peer review process".

Writing in the Wall Street Journal, Frederick K. Seitz, a physicist who is a past chairman of the advisory board of the Strategic Defense Initiative and now president of the George C. Marshall Institute, a conservative science policy organization, attacked the Intergovernmental Panel on Climate Change (IPCC).

Seitz repeated claims made last week by the Global Climate Coalition (GCC), an industry lobby group, in a letter circulated to congressmen and the White House, that the authors had no right to modify the text, which had been agreed after two rounds of government and expert peer review (see Nature 381, 546; 1996).

But he went further by suggesting that the authors' actions, "whatever the intent", effectively deceived both policymakers and public into believing that science blamed human activities for global warming. Seitz added that the best course of action would now be to "abandon the entire IPCC process".

The IPCC immediately fired off a reply to the newspaper. Its officials say that Seitz did not once contact the IPCC to get "both sides of the story", but simply rehashed arguments put forward by the
GCC. Meanwhile, 40 authors and contributors to the IPCC report have written separately to the Wall Street Journal defending the IPCC and Ben Santer, an atmospheric scientist at the Lawrence Livermore National Laboratory in California who acted as the 'lead author' of chapter eight, from charges of acting improperly.

Santer and his co-authors continue to argue that the changes improve the "scientific clarity" of the chapter and that the conclusion - suggesting evidence for a "discernible" human influence on global climate" - remains unchanged from both the draft and the final, published text.

But the GCC remains unconvinced. John Shlaes, executive director of the GCC, says the authors altered the science of the report and removed an entire summary, resulting in undue emphasis on a human role in global warming.

Santer says the IPCC rules of procedure state that full reports - as opposed to summaries - do not need to be "approved in detail", implying that late modifications by lead authors are allowed. He argues that this view was endorsed by the State Department, which, in a letter to the IPCC dated 15 November 1995, said: "In keeping with past practice in working group I, it is essential that the chapters not be finalized prior to completion of discussions at the IPCC working group I plenary in Madrid, and that chapter authors... modify the text in an appropriate manner following discussion in Madrid."

Ehsan Masood 